\title{
Bacteriological Quality Assessment of Milk in College of Veterinary Medicine (Cvm) Dairy Farm and Kalamino Dairy Farm in Mekelle, Tigray, Ethiopia
}

\author{
Faisal Said Mohamed* and Ahmed Ali Farah \\ Consultant Research of Ministry of Livestock and Animal Husbandry, Mekelle University, Ethiopia
}

Submission: October 28, 2018; Published: November 20, 2018

*Corresponding author: Faisal Said Mohamed, Mekelle University, College of Veterinary Medicine, Mekelle, Ethiopia

\begin{abstract}
Milk is an important source of nutrients to human and animals, but due to its high-water activity and nutritional value, it serves as an excellent medium for growth of many kinds of microorganisms under suitable conditions. The present cross-sectional study was conducted to assess hygienic practices, determination of bacterial quality of milk and isolation and identification of bacterial pathogens in milk at each critical control point throughout the value chain in MU-CVM and Kalamino dairy farms in Mekelle from August to November 2017. A total of 40 respondents were interviewed and subsequently, 84 milk samples were collected for laboratory analysis including bacterial load assessment and isolation and identification of bacteria. Total bacterial plate counts from milk were conducted. Isolation and identification of the bacteria in the milk was also conducted following standard methods. Results showed that, attendants of study dairy farms, managing their cattle in moderate hygienic environments and practicing intensive farming system.

The mean total bacterial plate counts of raw milk samples analyzed were $2.15 \times 108 \mathrm{cfu} / \mathrm{ml}$ (udder), $3.4 \times 108 \mathrm{cfu} / \mathrm{ml}$ (storage area in the farm) and $5.96 \times 108 \mathrm{cfu} / \mathrm{ml}$ (distribution center milk container). The increment of both counts at each critical control points was observed statistically significant $(\mathrm{P}=0.000)$. However, there was no significant variation between the two farms $(\mathrm{P}=0.074)$ in the mean total bacterial count. About $26.7 \%, 50 \%$ and $62.5 \%$ from teat, storage area in the farm and distribution center milk containers, respectively at MU-CVM and $40.9 \%$ from the teat, $62.5 \%$ from milk storage area and $75 \%$ from distribution center milk containers, respectively at Kalamino dairy farm were graded of poor quality. In the course of this study, the frequent bacterial pathogens isolated from raw milk samples taken from different critical points include: E. coli, S. aureus and Streptococcus spp. From the result there were hygienic practices in the study farms, but the quality of milk used for human consumption area was found inferior quality according the standard level. Thus, it is important practice proper and restricts hygienic practices, proper transportation and storage and reducing the milk storage time, raising the awareness of dairy workers to enhance the quality of milk used for human consumption.
\end{abstract}

Keywords: Bacterial load; Bacterial isolation; Critical control point; Dairy farms; Milk

Abbreviations: TDA: Tigray Development Association; TMTC: Too Many To Count; TFTC: Too Few To Count; NSS: Normal Saline Solution; TBPC: Total Bacterial Plate Counts

\section{Introduction}

Cow milk has long been considered a highly nutritious and valuable human food and it is consumed by millions daily in a variety of different products [1]. Raw milk of good hygienic quality meets the nutritional needs of body better than any single food as it contains essential food constituents such as fat, proteins, carbohydrates, minerals and vitamins [2]. As a result of the presence of these nutritional components, milk is an excellent culture medium for many microorganisms, especially bacterial pathogens [3]. Milk is often prone to early contamination and spoilage if not handled properly [4].

Microorganisms present in milk can be classified into two main groups: pathogenic and spoilage organisms, although some may play a dual role for example Bacillus cereus. Pathogenic organisms are those capable of inducing food poisoning, thus posing a threat to public health [5]. These pathogenic microbial contaminants in milk have been a major factor for public health concern since the early days of dairy industry [6]. There is a constant challenge to those involved in milk production to prevent or minimize the entry and subsequent growth of microorganisms in milk [7]. These is mainly due to the importance of producing milk of good hygienic quality, which is necessary to milk product of superior quality and prolonged shelf-life thereby to provide a safe and wholesome food for the consumers [7]. Bacterial contamination can generally occur from three main sources; within the udder, outside the udder and from the surface of equipment used for milk handling and storage [8]. 
Once milk is secreted out of the udder of the cow, the retention of milk requires cleanliness, sanitation and cooling [9]. Fresh milk drawn from a healthy cow normally contains a low microbial load of less than $103 \mathrm{cfu} / \mathrm{ml}$ [9]. However, the bacterial load may increase up to 100 -fold or more if stored for sometimes at ambient $\left(30\right.$ to $\left.35^{\circ} \mathrm{C}\right)$ temperature [10]. Milk produced under hygienic conditions from healthy animals should not contain more than 1 x $105 \mathrm{cfu} / \mathrm{ml}$.

Ethiopia possesses the largest livestock population in Africa. Estimates for farmer holding in rural areas indicate that the country has about 53.99 million heads of cattle, 24.6 million goats, 25.5 million sheep and 0.92 million camels [11]. In Ethiopia dairy production depends mainly on indigenous livestock genetic resources; more specifically on cattle, goats, camels and sheep. Cattle has the largest contribution (81.2\%) of the total national annual milk output, followed by goats $(7.9 \%)$, camels (6.3\%) and sheep (4.6\%).

While the industry is growing at a rapid rate, no milk quality standards currently exist, therefore, it is important to establish milk quality standards that focus on food safety measures in order to improve public health. This is one reason why milk testing and quality control include hygiene as well as microbial qualities in addition to testing for fat content and heat stability [12]. Prior to the discovery and widespread adoption of pasteurization for instance, raw milk and its products were responsible for serious bacterial infections such as diphtheria, scarlet fever and tuberculosis [13]. Consumers all over the world are increasingly concerned about the safety of their food in general and milk and milk products. Therefore, quality should not be ignored at all stages of the dairy value chain.

There is limited data on hygienic practices throughout the dairy production system in Ethiopia and standard milking procedures do not exist. A recent study in Ethiopia showed many farmers do not properly clean teats prior to milking. The study also showed a trend of farmers either not using a towel at all for disinfection or using a collective towel for two or more cows [14]. This practice can clearly lead to the spread of contagious pathogens. Raw milk is an important vehicle for the transmission of milk-borne pathogens to humans, as can be easily contaminated during milking and handling [15]. Poor or improper handling of milk can exert both a public health and economic constraints thus requiring hygienic vigilance throughout the milk value chain [16].

In some parts of the world including developing countries like Ethiopia, milk is still a significant source of these infections and other FBDs [17]. Consumption of raw milk and its derivatives is common in Ethiopia [18], which is not safe from consumer health point of view as it may lead to the transmission of various diseases. Raw or processed milk is a well know food medium that supports the growth of several microbes with resultant spoilage of the product or infections (intoxications) in consumers [19].
Even though milk represents an important place in the nutrition of consumers as well as nutrition and income of producers, there is limited work so far undertaken regarding assessment of bacteriological quality of raw cow milk in northern Ethiopia in general and dairy farms in the Mekelle particular. Determining the current status of bacteriological quality of milk at MU-CVM dairy farm and Kalamino dairy farm would create awareness on the bacterial safety in the milk and support for strengthening the hygienic standards practiced at different levels of the production chain. Thus, the present study is designed with the following objectives

a. To evaluate the hygienic practices and sanitary standards at MU-CVM and Kalamino dairy farms.

b. To determine the bacteriological quality of milk at the study dairy farms.

c. To isolate major bacterial species from milk samples having high bacterial load.

\section{Materials and Methods}

\section{Study Area}

MU-CVM and Kalamino dairy farms are in southern part of Mekelle city Tigray region, 13032' $\mathrm{N}$ and $39033^{\prime} \mathrm{E}$, and the city is $2200 \mathrm{~m}$ above sea level. The climate is semi-arid with an average annual rain fall of $600 \mathrm{~mm} / \mathrm{Hg}$ and the temperature ranges between 12 to $27.1^{\circ} \mathrm{C}$.

Both farms are intensive dairy cows, MU-CVM dairy farm is owned by the College of Veterinary Medicine of Mekelle University and Kalamino dairy farm is owned by Tigray Development Association (TDA). MU-CVM farm was established in August 2009 with 11 cows of HF cross breed, in 2012 it was modernized. During this study period 110 cattle were in the farm of which 84 were exotic breeds and 2 cross-breeds, and 30 of them were lactating cows. Kalamino dairy farm was established in 1997 (GC). On its establishment the farm has begun the project by 61 cross breed cows of HF and currently the farm has $87 \mathrm{HF}$ cows, with 22 lactating cows.

\section{Study Design}

A cross-sectional study was conducted from August to November 2017, to assess the general sanitary conditions of milking areas in dairy farms and examine bacteriological quality of milk. The study involved MU-CVM and Kalamino dairy farms and study unit was lactating cows in these farms where questionnaires were administered, and raw cow milk was collected for bacteriological analysis.

\section{Sample Size and Sampling Techniques}

First, a pilot survey was made in order to gather information on lactating cows of study dairy farms, fifty-two lactating cows were identified in the study farms (30 in MU-CVM and 22 in Kalamino dairy farms). In the farms there was a different critical control points throughout the value chain, such as milk collecting 
areas during milking. Both farms have milk distribution centers. The milk samples were collected from udder of all lactating cows, milk containers in the collection area and utensils of distribution center of farms. Thus, a total 84 samples (52 milk direct from teats in all lactating cow were taken, 16 (8 in each farm) from milk containers in collecting area immediately after milking and 16 (8 in each farm) from distribution sites immediately before distribution of milk samples were collected by random selection using sterile bottles. At all levels of sampling, the sampling bottles were capped, labeled with a permanent marker and transported to MU-CVM microbiology laboratory in an ice box, and stored at 4 ${ }^{\circ}$ C. Culturing was conducted within 24 hours after sampling [20].

\section{Questionnaire and Observational Survey}

Structured questionnaire (Annex1) was used to collect information from workers of study dairy farms, such as animal health workers, individuals involved in milking as well as handlers of the milk. Twenty respondents in each farm were interviewed with pre-coded response choices (closed-ended questions). The questionnaires were designed to get information on possible risk factors for bacterial contaminations in milk. Risk factors considered in the current study were sanitary conditions of the barn/milking environment, hygiene of milking cows' udder and milk handlers, hygiene of milking equipment with special emphasis to hygiene of milking procedures and milk handling practices, milk containers used for milking, storage and transportation. The questionnaire was administered through face to face interview. While administering questionnaires, direct observation on general cleanliness and hygienic conditions and practices about milk were also done and noted.

\section{Bacterial Load Assessment and Isolation}

\section{Total Bacterial Count}

The total bacterial count was made by adding $1 \mathrm{ml}$ of sample into sterile test tube having $9 \mathrm{ml}$ normal saline solution (NSS). After thoroughly mixing, the sample was serially diluted up to 1:10-6 and 1:10-7 then duplicate samples $(1 \mathrm{ml})$ were pour plated using 15-20 ml standard plate count agar solution and mixed thoroughly. The plated sample could solidify and then incubated at $37^{\circ} \mathrm{C}$ for 48 hours. Finally, counts were made using

\section{Results}

\section{Questionnaire and Observational Survey Result}

Table 1: Hygienic activities related to milk in the selected farms.

\begin{tabular}{|c|c|c|c|}
\hline Hygienic practices in the farms & MU-CVM dairy farm No= 20 & \\
\hline Water source for cleaning & $100 \%$ & $0 \%$ \\
\hline Pipe & $0 \%$ & \\
\hline Unprotected springs & $15 \%$ & $85 \%$ \\
\hline Cleaning frequency in barn and cow & $80 \%$ & $10 \%$ \\
\hline Daily & $5 \%$ & $5 \%$ \\
\hline Ono times a day & & \\
\hline
\end{tabular}

a colony counter after incubation of the cultures at $37^{\circ} \mathrm{C}$ for 48 hours. All colonies including those of pin point size were counted on selected plates using colony counter. Results from plates, which contained 30 to 300 colonies per plate were recorded. Plates with more than 300 colonies could not be counted and were designating as TMTC (too many to count) while plates with fewer than 30 colonies were designate as TFTC (too few to count). The plate counts were expressed as colony forming unit of the suspension ( $\mathrm{CFU} / \mathrm{ml}$ ) [21] and the average for each sample were recorded as $\mathrm{CFU} / \mathrm{ml}$. Samples were graded as very good if the total bacterial count did not exceed $2 \times 105 \mathrm{CFU} / \mathrm{ml}$, good if it was between $2 \times 105$ and $1 \times 106 \mathrm{CFU} / \mathrm{ml}$ and fair if the count was between $1 \times 106$ and $5 \times 106 \mathrm{CFU} / \mathrm{ml}$. Samples having bacterial count above $5 \times 106 \mathrm{CFU} / \mathrm{ml}$ were graded as poor quality [22].

\section{Bacterial Isolation}

Milk samples that were graded as poor quality were considered for bacterial isolation and identification. Isolation and identification of bacterial species was carried out based on conventional culture technique and biochemical assays. After thorough mixing of each milk samples, a loop full of the milk sample was streaked on the blood agar base enriched with 7\% sheep blood agar and MacConkey agar. Both agar plates were incubated at $37{ }^{\circ} \mathrm{C}$ and examined for bacterial growth after 48 hours and then bacterial colonies were identified. Pure culture colonies were selected and sub-cultured on nutrient agar (Oxoid UK) and incubated aerobically at $37{ }^{\circ} \mathrm{C}$ for $24-48$ hours for biochemical testing. The identification of the bacterial species was performed using biochemical tests and culturing on selective media. All media were prepared according to the manufacturer's specification [23].

\section{Data Analysis}

The data was entered excel spread sheet and analyzed using SPSS version 16.0 a statistical software. Percentages were also used to express the proportion of bacterial isolation and milk quality grade based on Indian standards. The differences in bacterial load between the samples from dairy farm, milk distribution center, hands of milkers and surface milk containers were compared. 


\section{Journal of Dairy \& Veterinary Sciences}

\begin{tabular}{|c|c|c|}
\hline Before starting of milking only & $20 \%$ & $60 \%$ \\
\hline Before and after of every cow & $80 \%$ & $35 \%$ \\
\hline Not wash & $0 \%$ & $75 \%$ \\
\hline Wash udder and teats before milking & & $25 \%$ \\
\hline Yes & $90 \%$ & \\
\hline No & $10 \%$ & $15 \%$ \\
\hline Dry udder materials & $15 \%$ & $75 \%$ \\
\hline Collective towel & $80 \%$ & $5 \%$ \\
\hline Individual towel & $5 \%$ & \\
\hline Hands & & \\
\hline Utensils cleaning & $50 \%$ & $20 \%$ \\
\hline Water with detergent & $0 \%$ & $10 \%$ \\
\hline Hot water & $50 \%$ & $70 \%$ \\
\hline Normal water & & \\
\hline
\end{tabular}

The floor of both farms was constructed with concrete materials (cement) where it facilitates easy cleaning. About $80 \%$ of the respondents at MU-CVM farm indicated they clean the barn two times daily, while in Kalamino farm $85 \%$ reported that they clean one's day. Both farms use tap water for cleaning the farm (Table 1). In both farms milking is done manually twice a day. The study farms use aluminum container (buckets) during

milking while MU-CVM and Kalamino farms use $75 \%$ and $95 \%$ metal pots, respectively for storage and transportation. Most of the respondents practiced washing of their milk utensils daily; while MU-CVM However, the cleaning is moderate in both but not efficient and utensils are not well dried. It was observed that milkers dip their fingers in the milking vessel to moisten teats of the cows with the intention of facilitating milking (Table 2).

Table 2: Milking and milk management practices in the CVM and Kalamino dairy farms.

\begin{tabular}{|c|c|c|}
\hline Milking and milk management & MU-CVM dairy farm N= 20 & Kalamino dairy farm $(\mathrm{No}=20)$ \\
\hline \multicolumn{3}{|l|}{ Milking method } \\
\hline Hands & $100 \%$ & $100 \%$ \\
\hline Machine & $0 \%$ & $0 \%$ \\
\hline Both & $0 \%$ & $0 \%$ \\
\hline \multicolumn{3}{|l|}{ Milking frequency } \\
\hline One's a day & $0 \%$ & $0 \%$ \\
\hline Two times a day & $100 \%$ & $100 \%$ \\
\hline Three times a day & $0 \%$ & $0 \%$ \\
\hline \multicolumn{3}{|l|}{ Utensils for milking and transport } \\
\hline Aluminum & $75 \%$ & $95 \%$ \\
\hline Plastic & $25 \%$ & $5 \%$ \\
\hline \multicolumn{3}{|l|}{ Milk storage } \\
\hline Refrigerator & $30 \%$ & $30 \%$ \\
\hline At room temperature & $0 \%$ & $20 \%$ \\
\hline Distribute after milking & $70 \%$ & $50 \%$ \\
\hline \multicolumn{3}{|l|}{ Mean of transportation } \\
\hline Private car & $60 \%$ & $85 \%$ \\
\hline Donkey & $40 \%$ & $0 \%$ \\
\hline Horse cart & $0 \%$ & $15 \%$ \\
\hline
\end{tabular}

In the present study, majority of the respondents across the milking. Generally, it was observed that the person involved in 2 farms wash their hands before milking, while around $80 \%$ of the millers at MU-CVM wash their hands before and after every cow milking, the rate of hand cleaning at Kalamino farm was $60 \%$. About $90 \%$ and $75 \%$ of the respondents at MU-CVM and Kalamino farms respectively indicated washing udder before milking was not clean; also, the hygiene milking environments was moderate, although Kalamino farm was low hygiene than the MU-CVM farm and the utensils for milking and transportation were looked well in both, but there were the possibilities indicated for microbial contaminations of milk. 
In both farms most of the milk was transported to their own milk distribution centers where their customers collect the milk. The milk distribution center of MU-CVM dairy farm is within the campus, but distribution centers of Kalamino dairy farm is in the down town of Mekelle city, therefore after milking takes time to reach the milk distribution center and there is opportunity increase of microbial contamination of milk.

\section{Bacterial Load and Quality of Milk Samples}

Total bacterial load: The mean for total bacterial plate counts (TBPC) of raw milk samples at three critical points Table 3: Summary of bacterial counts presented as CFU/ml from milk samples.

\begin{tabular}{|c|c|c|c|c|c|c|}
\hline Farms & Sample type & No of sample & Mean & Minimum count & Maximum count & p-value \\
\hline \multirow{4}{*}{ MU-CVM } & Teat & 30 & $1.56 \times 10^{8}$ & $1 \times 10^{7}$ & $3.6 \times 10^{8}$ & \multirow{4}{*}{$<0.001$} \\
\hline & SA & 8 & $2.49 \times 10^{8}$ & $9 \times 10^{7}$ & $6.2 \times 10^{8}$ & \\
\hline & DC & 8 & $5 \times 10^{8}$ & $2.9 \times 10^{8}$ & $7.9 \times 10^{8}$ & \\
\hline & Total & 46 & $2.98 \times 10^{8}$ & $1 \times 10^{7}$ & $7.9 \times 10^{8}$ & \\
\hline \multirow{4}{*}{ Kalamino } & Udder & 22 & $2.7 \times 10^{8}$ & $4 \times 10^{7}$ & $7.6 \times 10^{8}$ & \multirow{4}{*}{$<0.004$} \\
\hline & Teat & 8 & $4.06 \times 10^{8}$ & $2.6 \times 10^{8}$ & $5.6 \times 10^{8}$ & \\
\hline & DC & 8 & $6.9 \times 10^{8}$ & $4.2 \times 10^{8}$ & $1.08 \times 10^{9}$ & \\
\hline & Total & 38 & $4.4 \times 10^{8}$ & $4 \times 10^{8}$ & $1.08 \times 10^{9}$ & \\
\hline \multirow{3}{*}{$\begin{array}{c}\text { MU-CVM } \\
\text { Kalamino } \\
\text { Total }\end{array}$} & & 46 & $2.9 \times 108$ & $1 \times 107$ & $7.9 \times 108$ & \multirow{3}{*}{$<0.074$} \\
\hline & & 38 & $4.3 \times 108$ & $4 \times 107$ & $1.08 \times 109$ & \\
\hline & & 84 & $3.7 \times 108$ & $1 \times 107$ & $1.08 \times 109$ & \\
\hline \multirow{4}{*}{ CCPS } & Teat & 52 & $2.15 \times 108$ & $1 \times 107$ & $7.6 \times 108$ & \multirow{4}{*}{$<0.000$} \\
\hline & SA & 16 & $3.4 \times 108$ & $9 \times 107$ & $6.2 \times 108$ & \\
\hline & DC & 16 & $5.96 \times 108$ & $2.9 \times 108$ & $1.08 \times 109$ & \\
\hline & Total & 84 & $3.74 \times 108$ & $1 \times 107$ & $1.08 \times 109$ & \\
\hline
\end{tabular}

$\mathrm{SA}=$ Storage area in farm; DC = Distribution center in a farm; critical control points of sampling.

Likewise, TBPC increased by 2.56 x108 CFU/ ml from milking bucket in storage area at the farm level to distribution center milk container. The increase from point of production to distribution center milk containers was $3.81 \times 108 \mathrm{CFU} / \mathrm{ml}$. There was a difference in mean of total bacterial count between the farms where $2.98 \times 108$ and $4.4 \times 108 \mathrm{CFU} / \mathrm{ml}$ for milk samples collected from MU-CVM and Kalamino dairy farms, respectively. However, the difference was not statistically significant $(\mathrm{p}=$ 0.074), while analysis of variance indicated that there were statistically significant differences in total bacterial count $(\mathrm{p}<$ 0.001 ) between the critical points.

Quality of Milk Samples: Milk samples having total bacterial counts higher than acceptable level $(2 \times 106 \mathrm{CFU} / \mathrm{mL})$ according to Sherikar [22] were considered as poor quality. Out of the total milk samples collected from MU-CVM dairy farm, $26.7 \%$, $50 \%$ and $62.5 \%$ of the samples from direct cow's teat (udder), burkes in milk storage area and milk containers in distribution center, respectively were considered as poor quality while $40.9 \%, 62.5 \%$ and $75 \%$ milk samples collected from Kalamino dairy farm from direct cow's teat, buckets in milk storage area and milk containers at distribution center, respectively were graded as poor quality (Figure 1). within the two farms are shown in Table 3. The overall mean TBC was $2.15 \times 108,3.4 \times 108$ and $5.96 \times 108 \mathrm{CFU} / \mathrm{ml}$ for milk samples collected directly from the udder, milking container in temporary storage area in the farm and milk containers in distribution centers, respectively. There was an increasing trend of total bacterial count as the milk passed through udder, milking storage area and distribution centers. Accordingly, the count increased by $1.25 \times 108 \mathrm{CFU} / \mathrm{ml}$ from point of production (milk sampled directly from the teat) to milk samples taken from milking bucket in storage area at the farm.

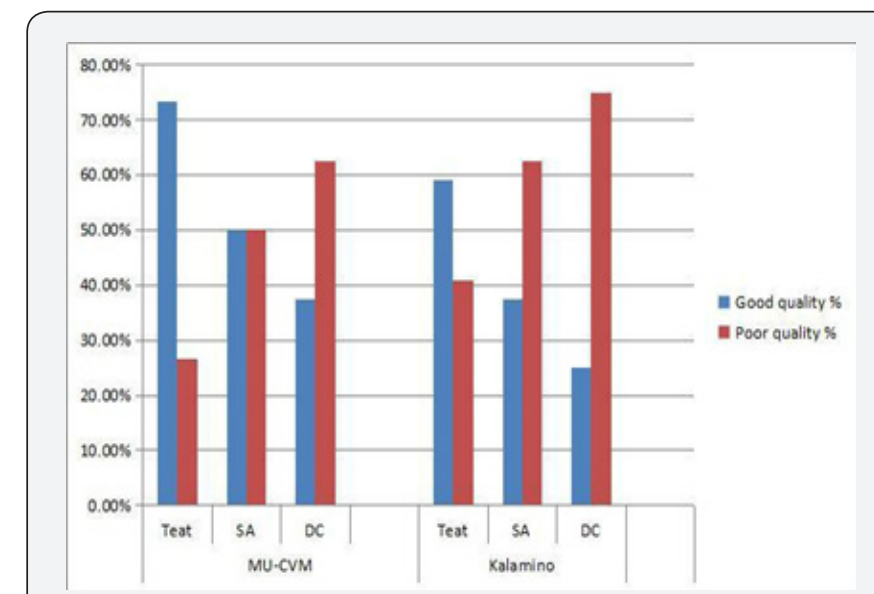

Figure 1: Quality of milk samples tested based on bacterial load compared with two farms.

\section{Bacterial Isolation}

The major bacteria isolated out of from milk samples having high bacterial load include S. aureus, Staphylococcus species other than S. aureus and Streptococcus species, E. coli, other coliform bacteria, Salmonella, Klebsiella and Pseudomonas (Table 4). 
Table 4: Bacterial isolates from raw milk samples of different sources.

\begin{tabular}{|c|c|c|c|c|}
\hline \multirow[t]{2}{*}{ Bacterial species isolated } & \multicolumn{3}{|c|}{ Milk source } & \multirow{2}{*}{$\begin{array}{c}\text { Total Prevalence } \\
\text { No. \% }\end{array}$} \\
\hline & Udder & SA & DC & \\
\hline S. aureus & 5 & 4 & 5 & $14(27.45)$ \\
\hline $\begin{array}{c}\text { Staphylococcus species other } \\
\text { than S. aureus }\end{array}$ & 2 & 2 & 1 & $5(9.8)$ \\
\hline Streptococcus species & 1 & 2 & 4 & 7 (13.7) \\
\hline E. coli & 1 & 4 & 4 & $9(17.6)$ \\
\hline Other coliform bacteria & 3 & 1 & 2 & $6(11.8)$ \\
\hline Salmonella & - & 1 & 2 & $3(5.9)$ \\
\hline Shigella & 1 & 1 & - & $2(3.9)$ \\
\hline Pseudomonas & 1 & 1 & & $2(3.9)$ \\
\hline Total & 15 & 16 & 18 & 51 \\
\hline
\end{tabular}

\section{Discussion}

The overall purpose of this study was to assess the hygienic condition and bacterial quality of raw cow milk in MU-CVM and Kalamino dairy farms in Mekelle. The result of questionnaire survey and observation in the study farms showed that milk was generally produced by dairy producers under moderate hygienic environmental condition. This study further revealed that both dairy farms managed their cattle in shaded cattle houses that are cleaned daily. Attendants try to clean environments but there are sources of milk contaminations. The present study also showed that most of the persons involved in milking activities were also not clean with their body and clothes during milking and milking utensils although better than traditional way, these possibilities predisposed milk to microbial contaminations at farm level.

It was further found that factors that were likely sources of microbial contamination in milk include hand milking in a same times dirty animal house, not washing udder and/or teats before and after milking with clean water and some milkers not drying the udder before milking. Most of the respondents (80\%) clean the barn on daily basis by removing the feces except weekends. Similar finding was also reported in Sidama highlands of Southern Ethiopia [24].

Milking was also performed in the same place after cleaning. Although, the high proportion of dairy cows their barn floors, clean, dry and comfortable bedding condition is important to minimize the growth of pathogenic microorganisms. Practices that expose the teat end to these organic bedding sources, wet and muddy pens increase the risk of occurrence of mastitis and milk contamination [25]. Unless properly handled, milk can be contaminated by microorganisms at any point from production to consumption. Producers should therefore make udder washing a regular practice in order to minimize contamination and produce good quality milk. Most of the respondents who practiced udder and teat drying use towel ( $80 \%$ in CVM $75 \%$ in Kalamino). It was reported by [26], that pre-milking udder preparation and teat sanitation play important part in the microbial load of milk, infection with mastitis, and environmental contamination of raw milk during milking. Cleaning the udder of cows before milking is important since it could have direct contact with the ground, urine, dung and feed refusals while resting. Lack of washing udder before milking can impart possible contaminants into the milk.

Production of milk of good hygienic quality for consumers requires good hygienic practices (clean milking utensils, washing milker's hands, washing the udder and use of individual towels) during milking and handling, before delivery to consumers or processors [27]. In the study area, most of the respondents practiced washing of their milk utensils. However, some of worker of study farms not uses detergents for cleaning and utensils are not properly dried. Surfaces such as milking equipment's' and hands meeting milk if not clean enough may cause milk contaminations. During the current study, aluminum containers were the major utensils for collection and storage of milk. In such a situation, microorganisms can rapidly build up in potentially nutritious milk residues of storage containers consequently contaminating the milk on subsequent uses. Contrary observations were also reported by Shija [28], who observed high microbial load in milk which was correlated with narrow necked plastic containers used in handling of milk.

The increment of bacterial load could be attributed to contamination of the milk throughout the value chain from production by different environmental factors through different exposures of contamination like pooling of milk from different animals together with unhygienic handling and leaving the milk without cooling. In the present study highest bacterial load was in distribution center and followed by bulks in storage area and least bacterial load was from milk collected directly from cow's teats (udder). This result agreed with the report by Zewdu [24] in Sidama highlands of Southern Ethiopia and Farah [29] in Somalia who also reported an increase in bacterial counts through milk value chain showing the highest count from bulk milk of cow stored for $24 \mathrm{hrs}$. without cooling. After milk passed one critical control point to another (from udder to temporary storage area) due to interactions of milk handles, transfer of milk in different containers and multiple sources the milk contamination rate will rise. This was also evidenced in the present study.

The mean total plate bacterial counts from teat milk samples was lower than mean value reported by Alehegne [30]. Similarly, the mean value of total plate bacterial counts for milk samples taken from the milking bucket in temporary storage area at farm level $(3.4 \times 108 \mathrm{CFU} / \mathrm{ml})$ were lower than that of previous reports for the same sample source [31]. The probable reason for the difference could be the use of aluminum containers which are easy to clean and better hygienic standards in the farms considered in the present study.

In general, present study is lower TPBC than majority of the previews study reported in Ethiopia due to improvement of hygiene on study farm and also these farms are generally proper milk hygiene and milking activities compared with reported 
dairy farming systems in Ethiopia in previous studies, although mean of TPBC observed in the current study was higher than the maximum recommended level of $2.0 \times 106 \mathrm{CFU} / \mathrm{ml}$. That mean as observed during sampling, high TPBC obtained in the current study might be related to the overall sanitary conditions followed which causes bacterial contamination in a milk.

Out of the total milk samples collected from MU-CVM dairy farm, $26.7 \%, 50 \%$ and $62.5 \%$ of the samples from direct cow's teat (udder), burkes in milk storage area and milk containers in distribution center, respectively were considered as poor quality while $40.9 \%, 62.5 \%$ and $75 \%$ milk samples collected from Kalamino dairy farm from direct cow's teat (udder), buckets in milk storage area and milk containers at distribution center, respectively were graded as poor quality, similarly by Redda [32] poor quality milk in dairy farms, cafeterias and wholesalers in Adigrat town of Tigray region.

The most predominant bacteria isolated in the present study were Staphylococcus spp. (37.25\%), Streptococcus spp. (13.7\%), Escherchia coli (17.6\%), other coliform bacteria spp. (11.8\%), Salmonella spp. (5.9\%), Shigellas pp. (3.9\%) and Pseudomonas spp. (3.9\%). These bacterial groups are the most common contaminants of raw milk and responsible for causing mastitis in dairy farms [33-36].

\section{Conclusion and Recommendations}

Milk intended for human consumption must be free from pathogens and must, if conditions permit, contain no or few bacteria. Clean milk could only be obtained if effective sanitary measures are taken starting from the point of milk withdrawn from the cow until it reaches the consumers [37]. From the findings of this study, it is concluded that; the milk produced by at MU-CVM and Kalamino dairy farms generally had higher TBPCs according to the international acceptable limits. Although, the mean TBPCs in the study farms were lower than previous reports, it calls for immediate action to improve the hygiene and sanitary measures at different critical points where milk could get contaminated. Majority of raw milk samples from distribution center containers for consumers had higher TBPCs, hence, its keeping quality would be lower and some of the pathogens present in the milk have public health significance.

Based on the findings of the present study, the following recommendations are made:

a. Raising the awareness of farm workers on good hygiene and sanitary measures could significantly reduce the contamination level

b. Ensuring proper transportation and storage of the milk, and reducing the milk storage time, at milk distribution centers should be considered.

c. Routine assessment of milk quality by the farms should be performed on a regular basis to ensure the supply of good quality milk to consumers.

\section{References}

1. Bramley AJ, McKinnon CH (1990) The microbiology of raw milk.

2. Medhammar E, Wijesinha-Bettoni R, Stadlmayr B, Nilsson E, Charrondiere UR et al. (2012) Composition of milk from minor dairy animals and buffalo breeds: a biodiversity perspective. Journal of the Science of Food and Agriculture 92: 445-474.

3. Saeed AEA, Zubeir EM, Owni OAO (2009) Antimicrobial resistance of bacteria associated with raw milk contaminated by chemical preservatives. World Journal of Dairy and Food Sciences 4(1): 65-69.

4. Ekici K, Bozkurt H, Isleyici O (2004) Isolation of pathogens from raw milk of different milk animals. Pakistan Journal of nutrition 3(3): 161162.

5. Logan NA (2012) Bacillus and relative food borne illness. Journal of Applied Microbiology 112: 417-429.

6. Altug G, Bayrak Y (2003) Microbiological analysis of caviar from Russia and Iran. Food Microbiology 2: 83-86.

7. O'Connor CB (1994) Rural diary technology ILCA training manual. Addis Ababa Ethiopia: International life stock Research Institute pp. 133.

8. Oliver SP, Jayarao BM, Almeida RA (2005) Food borne pathogens in milk and the dairy farm environment. Food borne pathogens and disease 2: 115-129.

9. Wallace RL (2009) Bacteria count in raw milk. Dairy cattle Management. p. 1-4.

10. Lingathurai S, Vellathurai P, Vendan SE, Prem AA (2009) A Comparative study on the microbiological and chemical composition of cow milk from different locations in Madurai, Tamil. Indian journal of science and technology 2(2): 51-54.

11. CSA (2013) Agricultural Sample Survey. Livestock, Poultry and Beehives population (private peasant holdings). Federal Democratic Republic of Ethiopia Central Statistical Authority (CSA), Addis Ababa, Ethiopia.

12. Giangiacomo R (2000) Milk testing, quality control, hygiene and safely. FAO e-mail conference on Small-scale milk collection and processing in developing countries pp. 108.

13. Spreer E (1998) Milk and dairy product technology. Mixa, A (translator). Marcel Dekker, New York, USA, p. 39-58.

14. Yilma Z (2010) Quality factors that affect Ethiopian formal milk business; experiences from selected dairy potential areas. Addis Ababa, Ethiopia: Netherlands Development Organization (SNV).

15. Pal M (2012) Public health hazards due to consumption of raw milk. The Ethiopian Herald, p. 10.

16. Swai ES, Schoonman L (2011) Microbial quality and associated health risks of raw milk marketed in the Tanga region of Tanzania. Asian Pacific Journal of Tropical Biomedicine 1: 217 - 222.

17. Shirima GM, Fitzpatrick J, Cleave land S, Kambarage DM., Kazwala RR, et al. (2003) Participatory survey on zoonotic diseases affecting livestock keeping communities in Tanzania. Journal of Animal and Veterinary Advances 2(4): 253 - 258.

18. Yilma Z (2003) Sanitary conditions and microbial qualities of dairy products in urban and peri-urban dairy shed of the central Ethiopia. DEA. Lyon, France.

19. Oliver SP, Boor KJ, Murphy SC, Murinda SE (2009) Food safety hazards associated with consumption of raw milk. Foodborne Pathogen and disease 6(7): 793-806.

20. Alganesh T, Ofodile LN, Fekadu B (2007) Microbial quality and chemical composition of whole milk from Horro cattle in East Wallega Ethiopia. Chemical Society of Nigeria 33(1): 31-36. 
21. Marth EH (1978) Standard Methods for the Examinations of Dairy Products. American Public Health Association, Washington pp. 416.

22. Sherikar AT, Bechhil VN, Thaplyal DC (2004) Text book of elements of Veterinary Public Health. Indian Council of Agricultural Research, New Delhi, India, pp: 75-120.

23. CLSI (2008) A standard for global application developed through the clinical and laboratory standards. Institute consensus process 28: 8 .

24. Zewdu M (2015) Hygienic practices, bacteriological quality of cow milk and its public health importance along the dairy value chain in Sidama high lands of southern Ethiopia. MSc Thesis, Addis Ababa University, College of Veterinary Medicine and Agriculture, Department of Microbiology, Immunology and Veterinary Public Health. p. 30.

25. Ruegg L (2006) Role of hygienic in efficient milking. WCDS advances in Dairy Technology. Department of Dairy Science, University of Wisconsin 18: 285-293.

26. Depiazzi LJ, Bell JR (2002) Effect of pre-milking teat sanitation on the quality of raw milk. Department of Agriculture, Government of Western Australia. South Western Highway Bunbury.

27. Getachew F (2003) A Review of the small-scale dairy sector in Ethiopia. FAO prevention of food losses programmed. milk and milk products, post-harvest losses and food safety in sub-saharan Africa and Near East.

28. Shija F (2013) Assessment of milk handling practices and bacterial contaminations along the dairy value chain in Lushoto and Handeni districts in Tanga region. MSc thesis, Sokoine University of Agriculture, Morogoro, Tanzania p. 1 - 88.

29. Farah M, Salik S (2007) Evaluation of bacteriological contamination in raw (unprocessed) milk sold in different regions of Lahore, Pakistan. Journal of Agriculture and Social Sciences Pakistan, 3(3): 104-106.
30. Alehegne W (2004) Bacteriological quality of Bovine milk in small holder dairy farms in Debrezeit, Ethiopia. Faculty of veterinary Medicine, Addis Ababa University, MSc thesis, Addis Ababa, Ethiopia p. 34 .

31. Bekele G, Bayileyegn M (2000) Bacteriological quality of raw cow's milk from four dairy farms and a milk collection center in and Around Addis Ababa. Berliner and Mucnchener Tieraerztliche Wochenschrift 113: 276-278.

32. Reda M, Taddele H, Afera B, Bsrat A (2014) Bacteriological Quality Assessment of Milk in Dairy Farms, Cafeterias and Wholesalers in Adigrat, Tigray, Ethiopia. European Journal of Biological Sciences 6 (4): 88-94.

33. Sivapalasingams S, Friedman CR, Cohen L, Tauxe RV (2004) Fresh produce: a growing cause of outbreaks of food borne illness in the United States. Journal of Food Protection 67: 2342 - 2353.

34. Donkor ES, Aning, KG, Quaye J (2007) Bacterial contaminations of informally marketed raw milk in Ghana. Ghana Medical Journal 41: 58 $-61$.

35. Abeer AA, Gouda SA, Dardir HA, Ibrahim AK (2012) Prevalence of some milk bacterial pathogens threatening cow milk consumers in Egypt. Global vet Link: Online Animal Health Solutions, 8: 76-82.

36. Abera BH, Assefa EK, Gebreselasse HK (2008) Assessment of bacteriological quality of raw cows' milk in Ab-'Ala, north eastern Ethiopia. Livestock Research for Rural Development 3: 1-4.

37. Robinson RK (2010) Elsevier Science Publishers, London, UK, pp. 163208. 